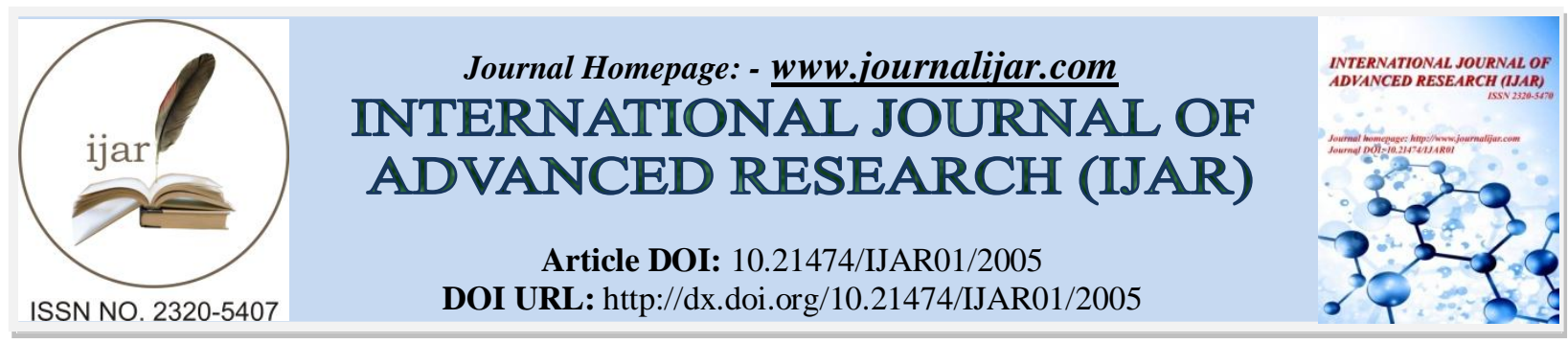

RESEARCH ARTICLE

\title{
BIOLOGICAL IMPACT OF CINNAMON EXTRACT VS. DIAZEPAM ON SUBMANDIBULAR SALIVARY GLANDS OF STRESSED ALBINO RATS.
}

\author{
Elham Hassan Hassan ${ }^{1 *}$, Laila Elsayed Amin ${ }^{2}$, Mohamed I. Mourad ${ }^{3}$ and Heba Mahmoud Elsabaa ${ }^{4}$. \\ 1. Demonstrator of Oral Biology, Faculty of Dentistry, Mansoura University, Egypt. \\ 2. Lecturer of Oral Biology, Faculty of Dentistry, Mansoura University, Egypt. \\ 3. Lecturer of Oral Pathology, Faculty of Dentistry, Mansoura University, Egypt. \\ 4. Professor of Oral Biology, Faculty of Dentistry, Mansoura University, Egypt.
}

\section{Manuscript Info}

n......................

Manuscript History

Received: 18 September 2016

Final Accepted: 27 October 2016

Published: October 2016

Key words:-

iNOS, diazepam, NT-3 gene, CIN

\section{Abstract}

Background and Objective: Cinnamon extract and diazepam found to have an ameliorative impact against anxiety influenced changes in salivary glands. Thus, this study was conducted to demonstrate and compare the possible biological impact of cinnamon extract versus diazepam upon submandibular salivary glands of stressed albino rats.

Material and Methods: Forty eight adult male albino rats, were divided randomly into 4 equal groups; negative control group I, group II, III \& IV rats were subjected to chronic restraint stress 6 hours daily for 15 days. The rats of groups III and IV were concomitantly received cinnamon oil extract or diazepam respectively. Six rat of each group were euthanized on $16^{\text {th }}$ day while the rest was euthanized on $30^{\text {th }}$ day. The specimens from submandibular salivary glands were prepared for staining with H\&E, iNOS stains and NT-3 gene expression via RT-PCR. The obtained data were tabulated, coded then analyzed using SPSS.

Results: Control group revealed normal structural and architectural features of normal salivary glands. Groups II, III and IV showed variable atrophic changes of acini and ductal cells after $16^{\text {th }}$ day. While, on $30^{\text {th }}$ day, salivary glands showed up about with typical histological features. The highest level of iNOS and NT-3 gene expression was observed in group II at the two examination periods. Statistically, there was an overall significant difference between all groups in relation to all studied parameters.

Conclusion: Cinnamon extract could protect or delay various neurodegenerative disorders. Also, it may be a valuable alternative for diazepam in management of stress-induced changes.

Copy Right, IJAR, 2016,. All rights reserved.

\section{Introduction:-}

Living in a modern society is often associated with more stressful social conditions ${ }^{[1]}$. Stress is a feedback survival response that strengthens the physical and mental status of an individual. Extreme stress may compromise mental and somatic health and lead to depression, immune suppression, hypertension and endocrine disorders ${ }^{[2]}$. Repeated stress is an important risk factor for the development of depression ${ }^{[3]}$. Stress, especially chronic stress, is one of the 
most important factors responsible for the precipitation of affective disorders in humans ${ }^{[4]}$. Moreover, stress has increased the number of patients who suffer from depression, affecting their quality of life and, subsequently, the socioeconomic balance ${ }^{[1]}$.

Salivary composition undergoes fluctuations due to the influence of various factors: daily and seasonal circadian rhythms ${ }^{[5]}$, taste and smell ${ }^{[6]}$ and acute mental stress ${ }^{[7,8]}$. The complex patterns of salivary responsiveness during mental stress are reflected by an increase in total salivary protein concentration ${ }^{[7-9]}$ and changing cortisol levels ${ }^{[10]}$. Increased total protein concentration after short-term acute stress changes the chemical properties of saliva, such as the adhesion or lubrication of oral surfaces ${ }^{[7]}$.Submandibular salivary gland plays an important role in the secretion of saliva which contains inorganic compounds, multiple proteins, glycoproteins and enzymes that affect the conditions of oral cavity ${ }^{[11]}$.

Various drugs are currently used to manage stress and depression, including diazepam, caffeine and certain anabolic steroids ${ }^{[2]}$.Diazepam is mainly used to treat anxiety, insomnia, and symptoms of acute alcohol withdrawal. It is also used as a premedication for inducing sedation, anxiolysis, or amnesia before certain medical procedures as endoscopy ${ }^{[12]}$. In addition, it possesses anticonvulsant, hypnotic, sedative, and skeletal muscle relaxant ${ }^{[13]}$. However, these drugs may be associated with severe toxicity and side effects ${ }^{[2]}$. Thus, stress management through dietary modifications ${ }^{[1]}$ and natural herbs may be a valuable alternative to antidepressant drugs ${ }^{[2]}$. Natural plantderived antioxidants are in high demand due to their potential in health promotion, disease prevention, and their improved safety and consumer acceptability ${ }^{[14,15]}$.

Cinnamon (CIN) may serve as potential dietary source of natural antioxidants for improving human nutrition and health ${ }^{[16]}$. It is rich in natural polyphenolic compound which act as reactive oxygen and nitrogen species scavengers, and enzyme modulators ${ }^{[17]}$.

Stress increases the activity of a calcium-independent nitric oxide NO synthase and induces the expression of inducible $\mathrm{NO}$ in cortical neurons ${ }^{[18]}$. Nitric oxide plays an important role in numerous physiological and pathophysiological conditions, as blood pressure regulation, inflammation, and infection, as well as initiation and progression of malignant diseases ${ }^{[19]}$.

Neurotrophin 3 (NT-3) is a member of the neurotrophin gene family which supports the survival of specific neurons. Neurotrophin 3 was shown to prevent the death of adult central noradrenergic neurons in vivo, a neuronal population which is associated with the pathophysiology of major depression ${ }^{[20]}$.

Concluded from the previous studies, cinnamon extract as well as diazepam may have a protective effect upon stress induced changes in salivary glands. Thus, this study will conducted to demonstrate and compare the possible biological impact of cinnamon extract versus diazepam on submandibular salivary glands of stressed albino rats.

\section{Material and Methods:-}

Animal subject:-

Forty eight adult male albino rats, weighing 150 to $200 \mathrm{~g}$ were selected for this study. The animals were housed and cared according to the guidelines of Ethical Committee, Faculty of Dentistry, University of Mansoura, Egypt. They were kept in individual cages and received standard food for rodents and tap water. They were kept in a light controlled room were $(12: 12-\mathrm{h})$ light, dark cycle and temperature $\left( \pm 22^{\circ} \mathrm{C}\right)$ and relative humidity $(65-70 \%)$ will be kept constant. They received commercial soft diet and water. They were weighed before the experiment.

\section{Experimental protocol:-}

After one week of acclimatization, the rats were classified randomly into four equal groups.

Group I:- (negative control group) Rats of this group received no treatment.

The other three groups of animals were kept in a mesh wire restrainer without food and water for 6 hours daily ( 9 AM: 2 PM)for 15 days $^{[21]}$. The dimensions of the mesh wire restrainer were $22 \times 10 \times 8 \mathrm{~cm}$.

Group II:- (positive control group) Rats of this group received no treatment in combination with the stress application. 
Group III:- (CIN oil extract group) Rats of this group were administered $0.5 \mathrm{ml}$ CIN oil extract which is equivalent to CIN $200 \mathrm{mg} / \mathrm{kg} / \mathrm{day}^{[22]}$ for the same period of stress application via gastric tubelhour before stress application $(8$ $\mathrm{AM})$.

Group IV:- (diazepam drug group) The rats of this group were received diazepam (Neuril, Memphis Company) (1 $\mathrm{mg} / \mathrm{kg} /$ day injected intra-peritoneal $)^{[23]}$ for the same period of stress application $1 \mathrm{~h}$ prior to stress application (8 AM).

Six rats from each group were sacrificed on the $16^{\text {th }}$ day (the first examination period) while the remaining rats were sacrificed at the end of the experiment $\left(30^{\text {th }}\right.$ day).

The animals of the present study were subjected to

Serum levels of adrenocorticotrophic hormone (ACTH):-

Three $\mathrm{ml}$ of blood was drained from each rat periodically (every 5 days)and placed in tubes containing EDTA. These blood samples were utilized for detection of serum levels of (ACTH).

On each examination period, the selected animals were anesthetized with halothan then euthanized. Right and left submandibular salivary glands were surgically excised.

\section{Histopathological study:-}

The right submandibular glands were fixed immediately in $10 \%$ formaldehyde prepared in phosphate buffer saline (PBS) for 24 hours. After that tissue processing was completed using an automatic tissue processor, which took the tissue through a series of graded alcohol baths and then into xylen. After that, molten paraffin was used to permeate tissues. The processed tissues were embedded in paraffin blocks. Serial sections (4 microns thick) were obtained from each paraffin block, mounted on coated slides and dried for staining with ordinary hematoxylin and eosin and iNOS antibody.

Slides were digitized using Olympus ${ }^{\circledR}$ digital camera installed on an Olympus ${ }^{\circledR}$ microscope with $1 / 2$ X photo adaptor, using a $40 \mathrm{X}$ objective. The resulting images were analyzed with Intel ${ }^{\circledR} \mathrm{Core}^{\circledR} 3^{\circledR}$ based computer using VideoTest Morphology ${ }^{\circledR}$ software (Russia) with a specific built-in routine for immunohistostaining analysis and stain quantification.

Data were tabulated, coded then analyzed using the computer program SPSS (Statistical package for social science) version 17.0. Descriptive statistics were calculated in the form of Mean \pm Standard deviation (SD).

Student's $t$-test was used to compare between mean of two groups of numerical (parametric) data. While ANOVA test was used to compare between more than two groups of numerical (parametric) data. Moreover, Pearson correlation coefficient ${ }^{\circledR}$ test was used for correlating different parameters. $P$ value $<0.05$ was considered statistically significant.

\section{Real time polymerase chain reaction (RT-PCR):-}

The left submandibular gland was preserved in liquid nitrogen to be utilized for extraction and isolation of RNA to quantify NT-3 via RT-PCR.

\section{Results:-}

Serum levels of ACTH:-

At $16^{\text {th }}$ day

Group II showed the highest mean \pm SD among all studied groups while, group I showed the lowest mean \pm SD among all studied groups. Statistically, there were significant difference between group I in one hand and groups II, III and IV in the other hand. Also, there were significant difference between group II in one side and groups III and IV in the other side. Moreover, no significant difference was found between groups III and IV. Table (1) At $30^{\text {th }}$ day 
Table 1:- shows means \pm SD of the ACTH level at $16^{\text {th }}$ and 30 days

\begin{tabular}{|l|l|l|l|l|l|}
\hline \multirow{2}{*}{ ACTH level } & \multicolumn{3}{|c|}{ Mean \pm SD } & P value \\
\cline { 2 - 5 } & Group I & Group II & Group III & Group IV & \\
\hline At $16^{\text {th }}$ day & $81.58 \pm 1.11$ & $364.17 \pm 1.57$ & $98.17 \pm 1.33$ & $100.92 \pm 6.73$ & $<0.0001$ \\
P1 & & & & & \\
P2 & & $<0.0001$ & $<0.0001$ & $<0.0001$ & \\
P3 & & & $<0.0001$ & $<0.0001$ & \\
\cline { 4 - 5 } At 30 & & & 0.55 & \\
& & $249.46 \pm 1.61$ & $86.96 \pm 1.55$ & $83.96 \pm 1.74$ & $<0.0001$ \\
\hline P1 & $79.79 \pm 1.16$ & & & & \\
P2 & & $<0.0001$ & $<0.0001$ & 0.001 & \\
P3 & & & $<0.0001$ & $<0.0001$ & \\
\hline
\end{tabular}

Group II showed the highest mean \pm SD among all studied groups. While group I showed the lowest mean \pm SD among all studied groups. Statistically, there was an overall significant difference between all groups. There was a significant difference between group I in one hand and groups II, III and IV in the other hand. Also, there were significant difference between group II in one side and groups III and IV in the other side. Moreover, no significant difference was found between groups III and IV. Table (1)

\section{Hematoxylin and Eosin (H\&E) Stain findings:-}

Group I (negative control group) (at $16^{\text {th }}$ and $30^{\text {th }}$ days):-

The dissected submandibular salivary glands from the control group showed normal histological and architectural features of rat's submandibular salivary gland. The gland architecture showed a lobular configuration with interlobular and intralobular spaces or clefts. They showed secretory end piece (serous acini), duct system (intercalated ducts and striated ducts), granular convoluted tubule and connective tissue septa which divide the glands into lobes and lobules. The serous acini of the studied cases were composed of pyramidal cells with eosinophilic granular cytoplasm and spherical basally situated basophilic nucleus. The acini were rounded and had a narrow lumen. The intercalated ducts were small in diameter and lined with a single layer of cuboidal cells with eosinophilic cytoplasm and centrally situated nuclei. The striated ducts were larger than intercalated ducts and lined with simple columnar epithelium. Their lining cells exhibited round centrally placed nuclei, deeply stained eosinophilic cytoplasm and faint striations. The granular convoluted tubules (GCT) were numerous and large in size. They lined with columnar cells with eosinophilic and granular cytoplasm, while their nuclei were round basally or centrally placed. (Fig,1A, 1B)

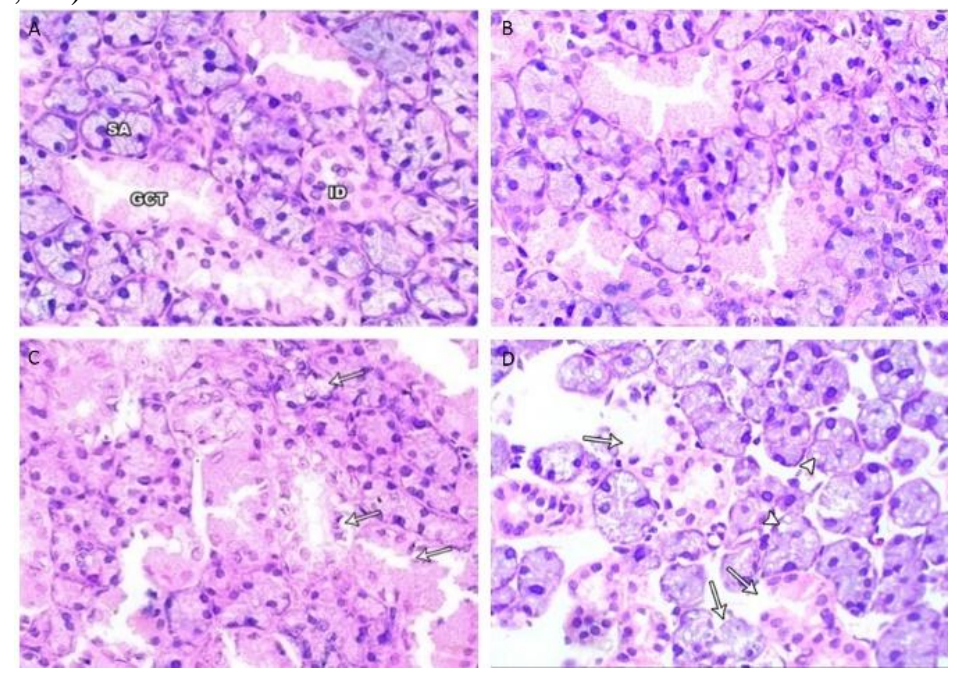

Fig 1:- photomicrograph showing pyramidal acinar cells with eosinophilic cytoplasm and spherical basally located basophilic nuclei. Normal histological architecture of serous acini (SA) and intercalated duct (ID) and granular convoluted tubules (GCT) in group I at $16^{\text {th }}$ day (A), normal histology in group I at $30^{\text {th }}$ day (B), submandibular salivary gland of group II at $16^{\text {th }}$ day showing areas of focal loss of acinar and ductal architectural features (arrow) 
Multiple intercellular vacuoles are seen (arrow head) (C), at $30^{\text {th }}$ day group II showed cytoplasmic vacuoles (arrow head) and focal loss of acinar and ductal outlines. (arrow) (D). (H\&E X 400).

\section{Group II (positive control group):-}

At $16^{\text {th }}$ day, acini showed atrophy and ducts were dilated and the interlobular and intralobular spaces as well. Cytoplasmic vacuoles were prominent and obvious within acinar and ductal cells as well as within cells of the GCTs.There were focal areas of loss of acinar and ductal architectural features. These areas showed partial absence of acinar and ductal as well as GCTs outlines. Degenerative changes as pyknotic nuclei and cytoplasmic vacuolation were observed at acinar and ductal cells. (Fig.1C) At $30^{\text {th }}$ day, submandibular salivary glands revealed normal histological and architectural features of rat's submandibular salivary glands, except for the presence of few cytoplasmic vacuoles, focal loss of acinar and ductal outlines and pyknosis of some nuclei. Acinar cells were conical in shape with granular eosinophilic cytoplasm and basally located basophilic round nuclei. (Fig.1D)

\section{Group III (CIN oil extract group):-}

The submandibular salivary glands dissected at $16^{\text {th }}$ day showed normal histological appearance of striated duct (SD), and intercalated duct (ID). Mild degenerative changes as cytoplasmic vacuoles within SA and some shrunked pyknotic nuclei are seen.(Fig.2A)At the end of the experiment, the submandibular salivary glands exhibited normal microscopical features. (Fig.2B)

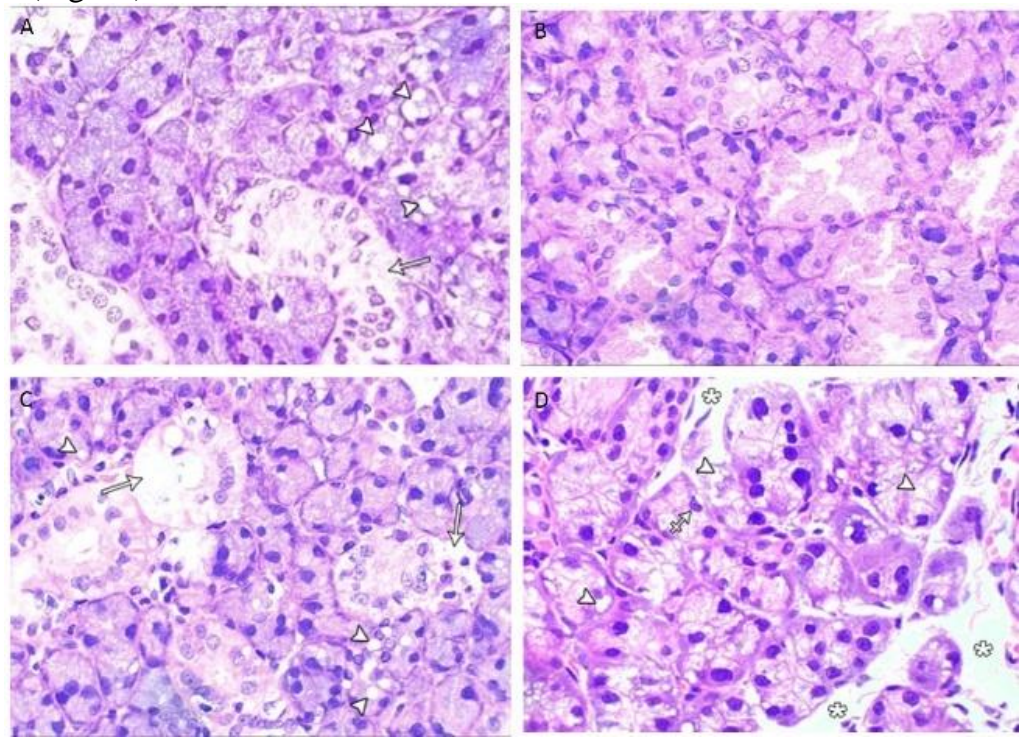

Fig 2:-photomicrograph showing loss of acinar outline and some pyknotic nuclei (crossed arrow), and cytoplasmic vacuoles (arrow head) in group III at $16^{\text {th }}$ day (A), histological appearance of serous acini (SA) in group III at $30^{\text {th }}$ day (B). Submandibular salivary gland of group IV dissected at $16^{\text {th }}$ day shows degenerative changes of acini and ducts (arrow) and cytoplasmic vacuoles (arrow head) (C).at $30^{\text {th }}$ day group IV shows degenerative changes of acini and pyknosis of nuceli (crossed arrow) and cytoplasmic vacuoles(arrow head) Wide connective tissue space are seen (star) (D) (H\&E X 400).

\section{Group IV (diazepam group):-}

On the first examination period, The examined glands revealed atrophy of most of serous acini with variable degrees of cytoplasmic vacuolation. The spaces between the lobes and the lobules were wider than normal. In addition, acini demonstrated marked degenerative changes such as atrophy and cytoplasmic vacuolation. (Fig.2C) Histological examination of the dissected glands at the end of the experiment revealed presence of some cytoplasmic vacuoles of variable sizes and pyknosis of some nuclei. Wide connective tissue spaces could be detected. (Fig. 2D)

\section{Immunohistochemical findings:-}

Cytoplasmic immunoreactivity for inducible nitric oxid synthase was detected in all studied groups with different levels. The highest level of iNOS expression was detected at group II while groups I, III and IV had nearly the same level of iNOS expression at $16^{\text {th }}$ day. Similar finding was detected at $30^{\text {th }}$ day examination period for groups I, III and IV while group II immuno-reactivity was dropped to nearly the same level of other examined groups. 
Statistically, ANOVA test revealed an overall significant difference between all studied groups at the two examination periods. At $16^{\text {th }}$ day, Posthoctukey test for multiple comparisons showed significant difference between group II on one side and groups I, III and IV on the other side. While, a non significant difference was found between groups III and IV as well as between group I on one hand and groups III, IV on the other hand. Moreover, there was no significant difference between each two groups at $30^{\text {th }}$ day. Table (2)

Table 2:- shows means \pm SD of the iNOS expression of rats of the studied groups at the two examination periods.

\begin{tabular}{|c|c|c|c|c|c|}
\hline \multirow[t]{2}{*}{ Periods } & \multicolumn{4}{|c|}{ means \pm SD of the iNOS expression } & \multirow[b]{2}{*}{$\mathrm{P}$} \\
\hline & Group I & Group II & Group III & Group IV & \\
\hline $16^{\text {th }}$ day & $\begin{array}{l}15,413,314.00 \pm 219 \\
, 370.88\end{array}$ & $\begin{array}{l}51,451,416.83 \pm 171 \\
, 866.78\end{array}$ & $\begin{array}{l}15,454,123.67 \pm 152 \\
, 489.20\end{array}$ & $\begin{array}{l}15,432,464.17 \pm 135 \\
, 612.27\end{array}$ & $<0.0001$ \\
\hline $\mathrm{P} 1$ & & $<0.0001$ & 0.97 & 0.99 & \\
\hline P2 & & & $<0.0001$ & $<0.0001$ & \\
\hline P3 & & & & 0.99 & \\
\hline $30^{\text {th }}$ day & $\begin{array}{l}15,149,001.67 \pm 80 \\
607.61\end{array}$ & $\begin{array}{l}15,444,335.00 \pm 300 \\
, 020.55\end{array}$ & $\begin{array}{l}15,244,925.33 \pm 89 \\
844.30\end{array}$ & $\begin{array}{l}15,419,246.50 \pm 147 \\
, 741.15\end{array}$ & 0.026 \\
\hline P1 & & 0.06 & 0.78 & 0.07 & \\
\hline $\mathrm{P} 2$ & & & 0.24 & 0.99 & \\
\hline P3 & & & & 0.35 & \\
\hline
\end{tabular}

SD: standard deviation P:Probability

Test used: ANOVA followed by posthoctukey for multiple comparisons

P1: Significance relative to Group I

P2: Significance relative to Group II

P3: Significance relative to Group III

By comparing the studied groups at the two examination periods in relation to iNOS expression, there was only significant difference between the two examination period of group II while other groups showed no significant difference. Table (3)

Table 3:- shows mean \pm SD of the iNOS expression at the different studied groups. Student's t- test was used for comparison between the studied groups and their selves at the two examination periods.

\begin{tabular}{|l|l|l|l|}
\hline \multirow{2}{*}{ Groups } & \multicolumn{2}{|c|}{ Mean \pm SD } & \multirow{2}{*}{ P } \\
\cline { 2 - 4 } & $16^{\text {th }}$ day & $30^{\text {th }}$ day & \\
\hline Group I & $15,413,314.00 \pm 219,370.8$ & $15,149,001.66 \pm 80,607.61$ & 0.12 \\
\hline Group II & $51,451,416.83 \pm 171,866.77$ & $15,444,335.00 \pm 300,020.55$ & $<0.0001$ \\
\hline Group III & $15,454,123.66 \pm 152,489.20$ & $15,244,925.33 \pm 89,844.30$ & 0.097 \\
\hline Group IV & $15,432,464.16 \pm 135,612.27$ & $15,419,246.5 \pm 147,741.14$ & 0.88 \\
\hline
\end{tabular}

Pearson's correlation test revealed significant positive correlation between iNOS and ACTH levels at $16^{\text {th }}$ day. On the other side, non significant correlation was detected between iNOS expression and ACTH level at $30^{\text {th }}$ day. Table(4).

Table 4:- shows statistical correlations between iNOS and ACTH level at both examination periods.

\begin{tabular}{|l|l|l|}
\hline Correlated variables & $\mathrm{R}$ & $\mathrm{P}$ value \\
\hline ACTH versus iNOS expression at $16^{\text {th }}$ days & 0.998 & .000 \\
\hline ACTH versus iNOS expression at 30 days & 0.375 & 0.071 \\
\hline
\end{tabular}


NT-3 gene expression;-

\section{At $16^{\text {th }}$ day Table(5);-}

NT-3 gene was expressed in all studied groups. Group II had the highest level of NT-3 gene expression. Groups I, III and IV nearly had the same level of expression at the two examination periods. The level of expression of NT-3 gene at $30^{\text {th }}$ day was decreased obviously and approached the level of the control group $(26.15 \pm 0.70,31.81 \pm 0.98)$, respectively.

Table 5:- shows means \pm SD of the NT-3 expression of rats of the studied groups at the two examination period.

\begin{tabular}{|c|c|c|c|c|c|}
\hline \multirow[t]{2}{*}{ Periods } & \multicolumn{4}{|c|}{ means \pm SD of the NT- 3 expression } & \multirow[b]{2}{*}{$\mathrm{P}$} \\
\hline & $\begin{array}{l}\text { Group } \\
\text { I }\end{array}$ & $\begin{array}{l}\text { Group } \\
\text { II }\end{array}$ & $\begin{array}{l}\text { Group } \\
\text { III }\end{array}$ & $\begin{array}{l}\text { Group } \\
\text { IV }\end{array}$ & \\
\hline $16^{\text {th }}$ day & $26.14 \pm 0.72$ & $46.14 \pm 0.72$ & $26.29 \pm 0.69$ & $26.53 \pm 0.53$ & \multirow[t]{4}{*}{$<0.0001$} \\
\hline P1 & & $<0.0001$ & 0.98 & 0.7 & \\
\hline $\mathrm{P} 2$ & & & $<0.0001$ & $<0.0001$ & \\
\hline P3 & & & & 0.9 & \\
\hline $30^{\text {th }}$ day & $26.15 \pm 0.70$ & $31.81 \pm 0.98$ & $26.36 \pm 0.80$ & $26.19 \pm 0.67$ & \multirow[t]{4}{*}{$<0.0001$} \\
\hline P1 & & $<0.0001$ & 0.97 & 1.00 & \\
\hline $\mathrm{P} 2$ & & & $<0.0001$ & $<0.0001$ & \\
\hline P3 & & & & 0.98 & \\
\hline
\end{tabular}

SD: standard deviation $\quad$ P:Probability

Test used: ANOVA followed by posthoctukey for multiple comparisons

P1: Significance relative to Group I

P2: Significance relative to Group II

P3: Significance relative to Group III

At the two examination periods, ANOVA test revealed an overall significant difference between all studied groups in relation to NT- 3 gene expression. Moreover, Posthoctukey test for multiple comparisons showed significant difference between groups I and II as well as between group II on one side and groups III, IV on the other side. While, there was no significant difference between groups III and IV as well as between group I on one hand and III and IV on the other hand.

By comparing the studied groups with their selves in relation to the NT-3 expression, there were non significant difference between the two examination periods except in group II. Table (6)

Table 6:- shows mean \pm SD of the NT-3 expression at the different studied groups. Student's t- test was used for comparison between the studied groups and their selves at the two examination periods.

\begin{tabular}{|c|c|c|c|}
\hline \multirow[t]{2}{*}{ Groups } & \multicolumn{2}{|l|}{ Mean \pm SD } & \multirow[t]{2}{*}{$\mathrm{P}$} \\
\hline & $16^{\text {th }}$ day & $30^{\text {th }}$ day & \\
\hline Group I & $26.13 \pm 0.71$ & $26.15 \pm 0.70$ & 0.29 \\
\hline Group II & $46.1383 \pm 0.71$ & $31.8 \pm 0.98$ & $<0.0001$ \\
\hline Group III & $26.28 \pm .68$ & $26.35 \pm .80$ & 0.8 \\
\hline Group IV & $26.52 \pm .53$ & $26.19 \pm .66$ & 0.19 \\
\hline
\end{tabular}

At the two examination periods,Pearson's correlation test revealed a significant positive correlation was found between NT-3 gene expression and ACTH level. Also, significant positive correlation between NT-3 gene expression and iNOS expression at $16^{\text {th }}$ day. On the other side non significant correlation was detected between Nt-3 gene expression, ACTH level and iNOS at $30^{\text {th }}$ day. Table (7) 
Table 7:- shows statistical correlations between NT-3 expression ACTH level and iNOS at both examination periods.

\begin{tabular}{|l|l|l|}
\hline Correlated variables & R & P value \\
\hline ACTH versus NT-3 expression at $16^{\text {th }}$ day & 0.996 & .000 \\
\hline NT-3 expression versus iNOS expression at $16^{\text {th }}$ day & 0.997 & .000 \\
\hline ACTH versus NT-3 expression at $30^{\text {th }}$ day & 0.958 & .000 \\
\hline NT-3 expression versus iNOS expression at $30^{\text {th }}$ day & 0.299 & 0.155 \\
\hline
\end{tabular}

\section{Discussion:-}

Epidemiological studies have indicated that a rising percentage of the population in modern societies are exposed to acute and/or chronic stress which can lead to variety of metabolic related disorders ${ }^{[24,25]}$.

In the present study, group II showed a significant elevation in serum ACTH at $16^{\text {th }}$ day. This agrees with Sun et $\mathrm{al}^{[26]}$, Maghsoudi et $\mathrm{al}^{[27]}$, and Michalska et $\mathrm{al}^{[28]}$, who found that chronic restraint stress elevates the circulating levels of ACTH and corticosterone. This could be referred to the effects of stressful stimuli upon the central nervous system and endocrine responses leading to excessive release of corticotropin releasing factor from hypothalamic paraventricular nucleus causing the secretion of ACTH from anterior pituitary. Moreover, with chronic stress, glucocorticoid feedback inhibition of ACTH secretion is reduced markedly. Thus, chronically stressed rats characteristically exhibit facilitated ACTH responses to stressors (restraint stress) ${ }^{[29]}$.

On the other hand, groups I, III, and IV of the present study yielded a non significant difference between each others. These findings may demonstrate the protective role of cinnamon and diazepam against the effects of stress and anxiety related behaviors ${ }^{[30-33]}$. This observation coincides with Roussel et al ${ }^{[30]}$, who stated that administration of cinnamon is related to biochemical changes toward normal control values as compared to that induced by a psychological stressor. Meanwhile, diazepam reduced the stress response and anxiety related conditions through its effect upon the hypothalamus and/or pituitary gland directly without the involvement of internal tissue. Additionally, this drug influences the activity of the hypothalamus-pituitary-adrenal axis in humans by reducing basal ACTH and cortisol release ${ }^{34}$.

In the current work, group II, III, and IV showed atrophic and degenerative changes of acini and ductal cells at $16^{\text {th }}$ day. These observed degenerative changes were pyknotic nuclei, cytoplasmic vacuoles and partial loss of acini, ductal or GCTs outlines. While at $30^{\text {th }}$ day, these studied groups exhibited nearly the same histological and architectural features of control group. These findings were in agreement with Bitgul et al ${ }^{[35]}$, El-Desouki et al ${ }^{[36]}$, and Pellegrni et $\mathrm{al}^{[37]}$ who proved that repeated stress, even of temporary duration, is able to influence directly or indirectly glandular tissues as adrenal cortex and testes. They explained the degenerative changes induced via immobilization stresses through the elevated excresion of corticosterone, serotonin, and catecholamine which play a role in lipid peroxidation ${ }^{[38]}$.

In our study, the submandibular salivary glands of group III dissected at $16^{\text {th }}$ day showed normal histological appearance. Mild degenerative changes as cytoplasmic vacuoles within serous acini and some shrunked pyknotic nucleiare seen. This is in agreement with Moselhy et $\mathrm{al}^{[39]}$ and Morgan et $\mathrm{al}^{[40]}$, who proved that cinnamon has antioxidant effect that may delay or inhibit the oxidation of lipids or other molecules by inhibiting the initiation, or propagation of oxidizing chain reactions. These involve absorption and neutralization of free radicals and attenuate ROS-mediated damage, resulting in more or less normal tissues ${ }^{[41]}$.

In the present study, submandibular salivary glands of group IV treated with diazepam revealed atrophy of most of serous acini with variable degrees of cytoplasmic vacuolation. The spaces between the lobes and the lobules were wider than normal.In addition, acini demonstrated marked degenerative changes such as atrophy and cytoplasmic vacuolation. These changes are milder than that appeared in group II. This is agreement with El-Desouki et al ${ }^{[36]}$ who stated that diazepam administration decreased the high levels of cortisol hormone induced by immobilization stress and revealed a remarkable improvement of alterations in the rats. Also, Zhao et al ${ }^{[42]}$ stated that diazepam slowed the progress of chronic stress induced-impairment of hippocampal structural plasticity and depression like behavior in mice by normalizing glucocorticoids. 
In the present study, group II showed high iNOS expression. This is in agreement with Olivenza et al ${ }^{[18]}$ who reported that chronic stress could induce iNOS expression and sustain overproduction of NO which might be responsible, at least in part, for some of the neurodegenerative changes in restraint rats. Chronic stress might induce expression of iNOS through the release of several proinflammatory cytokines such as interleukin-1 $\beta$ (IL-1B), TNF- $\alpha$ and interferon- $\gamma$ in various cell systems, including neurons. Large amounts of some of these cytokines, i.e., interleukin- $1 \beta$ and tumor necrosis factor- $\alpha$, are released in brain during stress ${ }^{[43-46]}$.

In the current work, non significant difference between groups I, II and IV in relation to the expression of iNOS was found. This finding could be supported by Kanuri et $\mathrm{al}^{[47]}$ who detected protective and anti inflammatory effects of CIN up on hepatic lipid accumulation. They attributed this protective effect to the association between CIN and inhibition of the induction of inducible nitric oxide synthase expression. Moreover, they indicated that cinnamon extract could suppress iNOS expression as well as NO formation almost completely.

Brahmachari et $\mathrm{al}^{[48]}$ reported that sodium benzoate, a major metabolite of cinnamon, attenuates the expression of iNOS and proinflammatory cytokines in microglia, astrocytes, and macrophages. Also, Gunawardena et al ${ }^{[49]}$, stated that the anti-inflammatory activity of cinnamon extract is measured by down-regulation of nitric oxide and TNF- $\alpha$ production. In addition Azab et al ${ }^{[50]}$ indicated that cinnamon antioxidant ingredients scavenge and stop the progress of ROS generation via stresses through direct scavenging of the initiating radicals, as well as decreased iNOS gene expression and subsequent NO production.

In the present study, group II had high levels of NT-3 mRNA gene expression within the submandibular gland. This is in accordance with Saruta et al ${ }^{[51]}$, who observed that immobilization stress increases NT-3 mRNA levels $n$ the rat hippocampus. This finding may be due to the presence of high brain NT-3 level which are markedly affected by stressful events. Moreover, they indicated that stress induced changes in NT-3 levels may be due to hormonal influences which might induce the increased expression of NT-3 within salivary glands. In addition, Smith et al ${ }^{[52]}$, demonstrated that corticosterone-mediated increases in NT-3 mRNA expression appeared to be primarily responsible for the effects of stress on NT-3. Also, Ivy et $\mathrm{al}^{[53]}$, Juric et $\mathrm{al}^{[54]}$ and O'Mahony et al ${ }^{[55]}$ have shown that increased levels of monoaminergic neurotransmitters, including adrenaline, noradrenaline, serotonin, and dopamine, induce BDNF and NT-3 expression in the brain under stress conditions.

In the current study, non significant difference was detected between groups I, III and IV in relation to expression of NT-3 mRNA. This is in accordance with Jana et $\mathrm{al}^{[56]}$ who recorded that cinnamon and its metabolite sodium benzoate are capable of upregulating neurotrophic factors. Also, they found that oral administration of ground cinnamon increased the level of sodium benzoate in blood and brain of mice and upregulated BDNF and NT-3 in vivo in the brain. Moreover, Bittigau et $\mathrm{a}^{[57]}$, found that histological examination of the brains of rats which received antiepileptic drugs as diazepam revealed widespread and dose-dependent apoptotic neurodegeneration during the brain growth spurt period. Also, they demonstrated that antiepileptic drugs lead to reduced expression of neurotrophins.

From the findings of the present study, we can conclude that; Chronic stress could lead a variety of metabolic, hormonal and neuronal disorders. Also, cinnamon extract and diazepam could efficiently modulate chronic stresses and consequently be a possible approach in reducing the risk of stress- induced various diseases. In addition it may have anti-inflammatory activity as it down regulates the expression of iNOS. Moreover, CIN could protect against or delay various neurodegenerative disorders as it reduces the expression of NT-3. Finally, cinnamon may be a valuable alternative for diazepam in management of stress- induced various diseases. 


\section{References:-}

1. Shinohara H., Fukumitsu H., Seto A., et al (2013). Medium-chain fatty acid-containing dietary oil alleviates the depression-like behaviour in mice exposed to stress due to chronic forced swimming. J Funct Foods. 5: 601-606.

2. Desai S., Desai S., Navdeep S., et al (2011). Antistress activity of Boerhaavia diffusa root extract and a polyherbal formulation containing Boerhaavia diffusa using cold restraint stress model. Int J Pharm Pharm Sci. 3:130-132.

3. Gregus A., Wintink A., Davis A., et al

Effect of repeated corticosterone injections and restraint stress on anexityand depression-

like behavior in malerats. Behav Brain Res. 156:105-114.

4. Rygula R., Abumaria N., Flügge G., et al (2005). Anhedonia and motivational deficits in rats: Impact of chronic social stress. Behavioural Brain Research. 162 :127-134.

5. Hansen A., Garde A. \& Persson, R (2008). Sources of biological and methodological variation in salivary cortisol and their impact on measurement among healthy adults: a review. Scand J Clin Lab . Invest 68, 448458.

6. Carpenter G (2013). The secretion, components, and properties of saliva. Annu Rev Food Sci Technol. 4, 267276.

7. Bosch J., Brand H., Ligtenberg T. et al (1996). Psychological stress as a determinant of protein levels and salivary-induced aggregation of Streptococcus gordonii in human whole saliva. Psychosom Med. 5: 374-382

8. Naumova E., Sandulescu T., Al Khatib P., et al (2012). Acute short-term mental stress does not influence salivary flow rate dynamics. PloS one 7, e51323.

9. Bosch J., de Geus E., Veerman E., et al (2003). Innate secretory immunity in response to laboratory stressors that evoke distinct patterns of cardiac autonomic activity. Psychosom Med. 65; 245-258

10. Tornhage C. J (2009). Salivary cortisol for assessment of hypothalamic-pituitary-adrenal axis function. Neuroimmunomodulation. 16, 284-289.

11. Kivelä J., Parkkila S., Metteri J., et al (1997). Salivary carbonic anhydrase VI concentration and its relation to basic characteristics of saliva in young men. Acta Physiol Scand. 161:221-225.

12. Bråthen G., Ben-Menachem E., Brodtkorb E., et al (2005). "EFNS guideline on the diagnosis and management of alcohol-related seizures: report of an EFNS task force". European Journal of Neurology : The Official Journal of the European Federation of Neurological Societies. 12 : 575-581.

13. Mandrioli R., Mercolini L. \& Raggi M (2008). "Benzodiazepine metabolism: an analytical perspective". Current Drug Metabolism. $9: 827-844$.

14. Gulcin I (2006). Antioxidant activity of caffeic acid (3,4dihydroxycinnamicacid), Toxicology. 217; 213-220.

15. Skerget M, Kotnik P, Hadolin M. et al (2005) Phenols, proanthocyanidins, flavones and flavonols in some plantmaterials and their antioxidant activities. Food Chem. 89: 191-198.

16. Su L., Yin J., Charles D., et a (2007)l. Total phenoliccontents, chelating capacities, and radical-scavenging properties ofblack peppercorn, nutmeg, rosehip, cinnamon and oregano leaf, FoodChem. 100: 990-997.

17. Rice-Evans. C., Miller. N., Papanga. G (1997). Antioxidant properties of phenolic compounds, Trends Plant Sci. 2:152-159.

18. Olivenza R., Moro M., Lizasoain I., et al (2000). Chronic stress induces the expression of inducible nitric oxide synthase in rat brain cortex. J Neurochem. 74:785-791.

19. Lirk P., Hoffmann G., Rieder J (2002). Inducible nitric oxide synthase--time for reappraisal. Curr Drug Targets Inflam Allergy. 1:89-108.

20. Hock C Heese K., Müller-Spahn F., Huber P., et al (2000). Increased cerebrospinal fluid levels of neurotrophin 3 (NT-3) in elderly patients with major depression. Molecular Psychiatry. 5:510-513.

21. Moazzam. S., Hussain M. \& Ahmad. T (2013). Effect of Chronic Restraint Stress on Immune Statusof Male Sprague Dawley Rats. Journal of the College of Physicians and Surgeons. 23: 487-490.

22. Howard C. Ansel PhD (2012). Pharmaceutical Calculations 13th Edition.

23. Drago F., Di Leo F., Giardina L (1999). Prenatal stress induces body weight deficit and behavioural alterations in rats: the effect of diazepam. European Neuropsychopharmacology. 9: 239-245.

24. Carlsson G., Gullberg B., Hafstrom L (1983). Estimation of liver tumer volume using different formulas -an experimental study in rats. J cancer Res Clin Oncal. 105:20-23.

25. Cosgrove M (2004). Do stressful life events cause type 1 diabetes? Occup Med. 54:250-254.

26. Sun Y., Liu F., Song G., et al (2006). Effects of acute and chronic restraint stress on visceral sensitivity and neuroendocrine hormones in rats. Chin J Dig Dis. 7:149-155. 
27. Maghsoudi N., Ghasemi R., Ghaempanah Z., et al (2014). Effect of Chronic Restraint Stress on HPA Axis Activity and Expression of BDNF and Trkb in the Hippocampus of Pregnant Rats: Possible Contribution in Depression during Pregnancy and Postpartum Period. Basic Clin Neurosci. 5: 131-137.

28. Gadek-Michalska A., Bugajski J (2003). Repeated handling, restraint, or chronic crowding impair the hypothalamic-pituitary-adrenocortical response to acute restraint stress. J Physiol Pharmacol. 54:449-459.

29. Dallman M., Akana S., Strack A., et al (2004). Chronic stress-induced effects of corticosterone on brain: direct and indirect. Ann N Y Acad Sci. 1018:141-150.

30. Roussel H., Hininger R., Benaraba T., et al (2009). Atioxidant effects of a Cinnamon extraction in people with impaired fasting glucose that are overweight or obese.J. Am. Coll. Nutr. 28: 16-21.

31. Giacomini A., Abreu M., Giacomini L., et al (2016). Fluoxetine and diazepam acutely modulate stress induced-behavior. Behav Brain Res. 296:301-310.

32. Lakehayli S., Said N., Khachibi M., et al (2015). Long-term effects of prenatal stress and diazepam on D2 receptor expression in the nucleus accumbens of adult rats. Neurosci Lett. 594:133-136.

33. Sander de Abreu M., Koakoski G., Ferreira D., et al (2014). Diazepam and Fluoxetine Decrease the Stress Response in Zebrafish. PLoS One. 9: e103232.

34. Gerlai R., Lahav M., Guo S., et al (2000). Drinks like a fish: zebra fish (Danio rerio) as a behavior genetic model to study alcohol effects. Pharmacol Biochem Behav. 67:773-782.

35. Bitgul G., Tekmen I., Keles D., et al (2013). Protective Effects of Resveratrol against Chronic Immobilization Stress on Testis ISRN Urol. 2013: 278720.

36. El-Desouki N., Gabry M., Nagi H (2015). Beneficial Role of Diazepam in the Histological Alterations of Colon Post Immobilization Stress-Induced in Adult Albino Rats. International Journal of Scientific \& Engineering Research, 6:432 ISSN 2229-5518.

37. Pellegrni A., Grieco M., Materazzi G., et al (1998). Stress induced morphohistochemical and functional changes in rat adrenal cortex, testis and major salivary glands. Histochem J 30:695-701

38. Barabo 1. V (1989). The role of lipid peroxidation in the mechanism of stress, Fiziologicheskii Zhurnal. 35: 85-97.

39. Moselhy S. \& ALI. H (2009). Hepatoprotective effect of Cinnamon extracts against carbon tetrachloride induced oxidative stress and liver injury in rats. Biol Res. 42: 93-98.

40. Morgan A., El-Ballal S., El-Bialy B., et al (2014). Studies on the potential protective effect of cinnamon against bisphenol A- and octylphenol-induced oxidative stress in male albino rats. Toxicology Reports. 1: 92101.

41. Osaw T., Uritani I., Garcia V., et al (1994). Novel natural antioxidants for utilization in food and biological systems. (Eds.), Postharvest Biochemistry of Plant Food-Materials in the Tropics, Japan Scientific Societies Press, pp. 241-251.

42. Zhao Y., Wang Z., Dai J., et al (2012). Benificial effects of benzodiazepine diazepam on chronic stressinduced impairment of hippocampal struc-tural plasticity and depression-like behavior in mice. Be-hav. Brain Res. 228: 339-350.

43. Minc-Golomb D., Tsarfaty I. \& Schwartz J (1994). Expression of inducible nitric oxide synthase by neurones following exposure to endotoxin and cytokine. Br J Pharmacol. 112:720-722.

44. Nathan C. \& Xie Q. Regulation of biosynthesis of nitric oxide (1994). J Biol Chem. 269:13725-13728.

45. Connor T. \& Leonard B (1998). Depression, stress and immunological activation:The role of cytokines in depressive disorders. Life Sci. 62:583-606.

46. Murray C. \& Lynch M (1998). Evidence that increased hippocampal expression of the cytokine interleukin-1 beta is a common trigger for age- and stress-induced impairments in long-term potentiation. Journal of Neuroscience. 18:2974-2981.

47. Kanuri G., Weber S., Volynets V., et al (2009). Cinnamon Extract Protects against Acute Alcohol-Induced Liver Steatosis in Mice. J.Nutr. 139: 482-487.

48. Brahmachari S., Jana A. \& Pahan K (2009). Sodium Benzoate, a Metabolite of Cinnamon and a Food Additive, Reduces Microglial and Astroglial Inflammatory Responses. The Journal of Immunology. $183: 5917-5927$.

49. Gunawardena D., Karunaweera N., Lee S., et al (2015). Anti-inflammatory activity of cinnamon (C. zeylanicum and C. cassia) extracts - identification of E-cinnamaldehyde and o-methoxy cinnamaldehyde as the most potent bioactive compounds. Food Funct. 6:910-919.

50. Azab K., Mostafa A., Ali E., et al (2011). Cinnamon extract ameliorates ionizing radiation-induced cellular injury in rats. Ecotoxicology and Environmental Safety. 74: 2324-2329. 
51. Saruta J., Iida M., Kondo Y., et al (2012). Chronic Stress Induces Neurotrophin-3 in Ratsubmandibular Gland. Yonsei Med J. 53:1085-1092.

52. Smith M., Makino S., Kvetnansky R., et al (1995). Stress and glucocorticoids affect the expression of brainderived neurotrophic factor and neurotrophin-3 mRNAs in the hippocampus.Neurosci.15:1768-1777.

53. Ivy A., Rodriguez F., Garcia C., et al (2003). Noradrenergic and serotonergic blockade inhibits BDNF mRNA activation following exercise and antidepressant. Pharmacol Biochem Behav. 75:81-88.

54. Juric D., Miklic S. \& Carman-Krzan M(2006). Monoaminergic neuronal activity up-regulates BDNF synthesis in cultured neonatal rat astrocytes. Brain Res. 1108:54-62.

55. O'Mahony C., Clarke G., Gibney S., et al (2011). Strain differences in the neurochemical response to chronic restraint stress in the rat: relevance to depression. Pharmacol Biochem Behav. 97:690-699.

56. Jana A., Modi K., Roy A., et al (2013). Up-regulation of neurotrophic factors by cinnamon and its metabolite sodium benzoate: Therapeutic implications for neurodegenerative disorders. J Neuroimmune Pharmacol. 8: 739-755.

57. Bittigau P., Sifringer M. \& Ikonomidou C (2003). Antiepileptic drugs and apoptosis in the developing brain. Ann N Y Acad Sci. 993:103-14; discussion 123-124. 